\title{
Picket Line Observance:
}

\section{The Board and the Balance of Interests}

When an employee refuses to cross a picket line at the business of an employer other than his own, divergent interests are brought into conflict. Union morality commands that workers not cross any picket lines; ${ }^{1}$ an employee's observance of a picket line not only aids the cause of the picketing employees but also strengthens the solidarity of the labor movement as a whole. From the perspective of an employer, however, the observance by his men of a picket line at another employer's establishment often entails substantial costs. The refusal of employees to pick up essential materials from a picketed supplier can close a business; the failure to service a picketed customer may mean the permanent loss of patronage. ${ }^{2}$

Should an employee refuse to cross a picket line at the premises of either his own employer or another employer and thereby not complete his assigned duties, the only statutory restrictions on his employer's freedom to discipline or discharge him are the unfair labor practices contained in Section 8(a) of the Labor-Management Relations Act. ${ }^{3}$ Those provisions protect against employer interference the rights granted to employees by Section 7 of that Act:

Employees shall have the right to self-organization, to form, join, or assist labor organizations, to bargain collectively through representatives of their own choosing and to engage in other concerted activities for the purpose of collective bargaining or other mutual aid or protection, and shall also have the right to refrain from any or all of such activities. ...4

It has been established that an employee who refuses to cross a lawful picket line at his own employer's premises and remains totally out of work is to be treated as a striker, even if he is not a member of the

1. J. BARBasi, LABOR UNions in Action 129 (1948).

2. In the case of a common carrier, the refusal of his emplojecs to service a picketed depot may make him liable for damages for breaching his statutory duty "to provide and furnish . .. transportation upon reasonable request therefor." Sec, e.g., Mlinneapolis \& St. Louis Ry. Co. v. Pacific Gamble Robinson Co., 215 F.2d 126 (8th Cir. 1951).

3. 29 U.S.C. § 158(a) (1964):

It shall be an unfair labor practice for an employer-(1) to interfere with, restrain, or coerce employees in the exercise of the rights guarantecd in section 157 of this title;... (3) by discrimination in regard to hire or tenure of employment or any term or condition of employment to encourage or discourage membership in any labor organization. ...

4. 29 U.S.C. \& 157 (1964). 
picketing union or part of the bargaining unit involved.5 Still not satisfactorily reconciled are the conflicting rights of labor and management when an employee refuses during the course of his duties to cross a labor picket line set up at the premises of an employer other than his own. While such a refusal is clearly not illegal, ${ }^{6}$ the extent to which Section 7 limits the employer's right to react remains unclear. ${ }^{7}$

At present, the National Labor Relations Board attempts to define the rights of employee and employer in this situation by balancing the competing interests. However, an analysis of the Board's proper role in the collective bargaining process leads to the conclusion that the Board should not undertake the function of reconciling the divergent interests but should instead leave it to the parties to work out their own accommodation in this area.

\section{The Case Law}

In dealing with employer-employee conflict over the observance of picket lines at other employers' premises, the National Labor Relations Board has acted with an inconsistency that has bred confusion. The

5. NLRB v. Southern Greyhound Lines, - F.2d - 74 LRRM 2080 (5th Cir. 1970); NLRB v. City Yellow Cab Co., 344 F.2d 575 (6th Cir. 1965); NLRB v. John S. Swift Co., 277 F.2d 641 (D.C. Cir. 1960). An economic striker cannot be discharged, but he may be permanently replaced. See NLRB v. Mackay Radio \&: Telegraph Co., 304 U.S. 393 (1938).

6. Section 8(b)(4) of the Act, 29 U.S.C. \& 158(b)(4), includes the proviso:

$[N]$ othing contained in this subsection (b) [the union unfair labor practice provi. sions] shall be construed to make unlawful a refusal by any person to enter upon the premises of any employer (other than his own employer), if the employecs of such employer are engaged in a strike ratified or approved by a representative of such employees whom such employer is required to recognize under this $A \mathrm{ct}$.

7. The legislative history of the 1947 Act includes but one brief explanation of the Section $8(\mathrm{~b})(4)$ proviso, note 6 supra, and no indication that Congress cven consldered the question of whether an employer should be free to discipline employees for refusing to cross picket lines at the premises of other employers or whether he was prohibited from so doing by Section 7 's protection of "concerted activities for the purpose of . . . mutual aid or protection." 1 LEGISLATIVE History OF THE LABOR MANAGEMENT RELATIONS ACr, 1947, at 429 (S.Rep. No. 105 on S.1126). Amendments relating to the problem were proposed in 1959, but no consensus of what the law was or what it should be was evident and the 8(b)(4) proviso remained unchanged. I LEGisLATIVE History of THE LAwon MANAgement RePorting AND Disclosure ACT of 1959, at 755.56, 779.80, 838; 2 id. at 1312-13, 1315-17, 1389, 1425, 1432, passim.

A literal reading of Section 8(a)(1), prohibiting all employer interference with "cm. ployees in the exercise of the right guaranteed by Section 7, , would prevent employers from opposing in any fashion any concerted activity by their employecs. This interpretation of the Act has never been accepted:

[T] here are many economic weapons which an employer may use that cither inter. fere in some measure with concerted employee activities, or which are in some degree discriminatory and discourage union membership, and yet the use of stuch economic weapons does not constitute conduct that is within the prohibition of either $\$ 8(a)(1)$ or $\& 8(a)(3)$.

NLRB v. Brown, 380 U.S. 278,283 (1965). Instead, the term "concerted activity" has been applied as a legal rather than a literal concept, with the Board determining what activities are protected and to what extent. See generally Cox, The Right to Engage in Concerted Activities, 26 IND. L.J. 319 (1951). 
first encounter with the problem came in 1950 when the Board declared unlawful a stockbroker's discharge of one of its employees for his refusal to cross a picket line established at the New York Stock Exchange. ${ }^{8}$ The Board declared the observance of the picket line to be "protected concerted activity" within the meaning of Section 7 and ordered reinstatement and back pay for the discharged employee.

The next year, in Rockaway News Supply Co., ${ }^{0}$ the Board explained that, although an employee's refusal to cross a lawful picket line at the plant of an employer other than his own was a "protected form of concerted activity," the employer, "as a normal incident of its right to maintain its operations," could require the employee to perform all his duties or to vacate his job and assume the position of a striker, thereby becoming subject to permanent replacement. Outright discharge of the employee, however, remained a violation of the Act.

On the Board's petition for enforcement in Rockaway News, the Court of Appeals for the Second Circuit rejected the Board's conclusion that the activity was "protected" and held that the employee's right to refuse to cross a picket line at another employer's establishment existed only when he was on his own time. ${ }^{10}$ The Supreme Court granted certiorari in the case, but then specifically refused to pass on the "protected concerted activity" issue. ${ }^{11}$ While affirming the Court of Appeals' reversal of the Board, the Court did so on the ground that the no-strike clause contained in the collective bargaining agreement governing the discharged employee's terms of employment was still valid. The employer, according to the Supreme Court, did not commit an unfair labor practice by discharging the employee since the latter's refusal to cross the picket line was a violation of the collective bargaining agreement, as interpreted in an earlier arbitration proceeding involving the same incident. ${ }^{12}$

Later in 1953, after the Eisenhower administration had replaced some of the Board members with its own appointees, the NLRB ignored its former rulings on an employee's refusal to cross a picket line at the premises of an employer other than his own, and in its Auto Parts Co. decision ${ }^{13}$ simply stated that

8. Cyril de Cordova \& Bro., 91 N.L.R.B. 1121 (1950).

9. 95 N.L.R.B. 336 (1951).

10. NLRB v. Rockaway News Supply Co., 197 F.2d III (2d Cir. 1952).

11. NLRB v. Rockaway News Supply Co., 345 U.S. 71, 75 (1953):

The parties here see the case as requiring decision of sweeping abstract principles as to the respective rights of employer and emplojee regarding picket lines. But this decision does not, and should not be read to, declare any such principles.

12. 345 U.S. at 81 .

13. 107 N.L.R.B. 242 (1953). 
[the employee's] conduct was a refusal to do the job for which he had been hired and a direct disregard of his employer's instructions. For such conduct he could properly be discharged. ${ }^{14}$

In the early months of 1961, with Eisenhower appointees still cormprising a majority, the Board in Redwing Carriers, Inc. ${ }^{15}$ affirmed its Auto Parts position; this time it specifically declared that an employee's refusal to cross a picket line at another employer's premises was "unprotected" activity, and hence grounds for discharge. ${ }^{16}$

Kennedy appointees gained control of the NLRB in the spring of 1961 and were apparently determined to waste no time in altering labor policy. ${ }^{17}$ The 1961 Redwing case, on appeal to the Court of Appeals for the District of Columbia, was remanded at the request of the Board for further consideration. In its second Redwing decision, ${ }^{18}$ the Board again held that the employer did not commit an unfair labor practice by discharging employees who refused to cross the picket line. In reaching this decision, however, the Board now announced that an employee's refusal to cross a picket line at another employer's premises was "protected".

Such activity is literally for "mutual aid or protection," as well as to assist a labor organization, within the meaning of Section $7 .^{10}$

Redwing Carriers had not violated the Act because its discharges were covered by the one exception to the new protected activity rule:

[T] he employer acted only to preserve efficient operation of his business, and terminated the services of the employees only so it could immediately or within a short period thereafter replace them with others willing to perform the scheduled work. . .20

14. Id. at 243. The Board considered it immaterial that the duties not performed by the employee related to the union activities of employees elsewhere. It refused cven to discuss or to adopt the Trial Examiner's comments on previous Board and Court decisions.

15. 130 N.L.R.B. 1208 (1961).

16. The Board's decision included no explanation of why such activity was unpro. tected, but in a footnote it cited cases for "the principle that employces cannot insist on remaining at work on their own terms and conditions, or that partial or intermittent work stoppages are unprotected. . . ." 130 N.L.R.B. at 1212 n.9.

17. See generally Grodin, The Kennedy Labor Board, in LABOR: REAdincs ON MAjon Issues 506 (Lester ed.1965).

18. Redwing Carriers, Inc., 137 N.L.R.B. 1545 (1962), enforced stb nom. Tcamstcrs Local 79 v. NLRB, 325 F.2d 1011 (D.C. Cir. 1963), cert. denied, 377 U.S. 905 (1961).

19. 137 N.L.R.B. at 1546-47. The Board first pointed out that the 1953 Auto Parts decision never specifically declared the activity unprotected and then cited the 1950 Cyril de Cordova \& Bro. decision, 91 N.L.R.B. 1121, and Cone Bros. Contracting Co., 135 N.L.R.B. 108 (1962), a one-month old decision by the new Board not fully on point.

20. 137 N.L.R.B. at 1547 (emphasis in original). 
The NLRB has on several occasions applied its Redwing doctrine,21 but the courts have never fully adopted it. On appeal, those Board decisions in which the doctrine has been determinative have either been affirmed on other grounds or reversed with at least implicit rejection of the Redwing approach.22

The practical problems of interpreting the concepts in the Redwing exception are extensive. Much of the difficulty stems from the attempt to equate the rights of an employee refusing to cross a picket line at the premises of an employer other than his own with the rights of an employee striking against his own employer..$^{23}$ Thus, under Redwing, the picket line observer, like the economic striker, 24 is subject to replacement but not outright discharge. In the context of an economic strike, replacement is a relatively identifiable act-someone has taken over the striking employee's entire job. In the case of the picket line observer, however, the employee most often refuses to perform not all his duties, but only those which must be performed at picketed premises.

Where the employer assigns another employee or a supervisor to do

21. See, e.g., Smith Transit, Inc., 176 N.L.R.B. No. 141 (1969); Alamo Express, Inc, 170 N.L.R.B. No. 26 (1968); Swaine \& Morris Construction Co., 168 N.L.R.B. No. 147 (1967); Thurston Motor Lines, Inc., 166 N.L.R.B. No. 101 (1967); Oremite Transportation Co., 164 N.L.R.B. 72 (1967); Overnite Transportation Co., 154 N.L.R.B. 1271 (1965), enforced in part sub nom. Truck Drivers Local 728 v. NLRB, 361 F.2d 682 (D.C. Cir. 1966); L.G. Everist, Inc., 142 N.L.R.B. 193, enforcement denied, 334 F.2d 312 (8th Cir. 1964).

22. In the appeal of the Redwing decision itself, the District of Columbin Court of Appeals avoided the merits of the doctrine, instead noting that under both the Auto Parts no-protection rule and the Redwing doctrine's replacement-for-business-nccessity exception, Redwing Carriers did not commit an unfair labor practice by discharging the picket line-observing employees. In Truck Drivers Local 728 v. NLRB, 364 F.2d 682 (1966), the District of Columbia Court of Appeals again avoided passing on the Redwing doctrine, this time by affirming a Section 8(a)(3) violation found by the Board; since the remedy of reinstatement was the same for both violations, there was no need for the court to consider the Section $8(a)(1)$ violation found by the Board's application of the Redwing doctrine. In Truck Drivers Local 413 v. NLRB, 334 F.2d 539 (1901), the same court did refer to its own Redwing decision as affirming the Board's holding of protection for the refusal to cross the picket line, but the ase involved the validity of a contract clause and the decision did not discuss the exception in Redwing or the merits of the doctrine itself.

Finally, the Court of Appeals for the Eighth Circuit, in NLRB v. Everist Co., 334 F.2d 312 (1964), in effect rejected the whole doctrine, although the court's decision did not specifically challenge the Board's declaration of the activity as "protected."

23. This analogy is not even the most appropriate. The picket line observer who refuses to perform only part of his work-the part that must be done at the picketed premises-can more closely be equated with a partial striker who receives no protection for similarly refusing to perform only part of his work. But this analogy too is not compelling since the partial striker, like the full striker, is conducting a primary action against his own employer; the employer can end the strike by yiclding to the demands of his employees. The employer confronted with an employec observing a picket line at the premises of another employer is only a secondary employer and has no means to terminate the picket line; the action is being directed against the picketed complojer and only that employer can act to end it.

24. NLRB v. Míackay Radio \& Telegraph Co., 304 U.S. 333 (1938). 
the picketed work, it is unclear whether the picket line-observing employee has been "replaced." In Thurston Motor Line, Inc.," for instance, the Board held the discharge of a driver lawful when, because of the presence of a picket line at one of his regular stops, a supervisor had to make a single delivery for him. In Overnite Transportation $\mathrm{Co}^{2}{ }^{26}$ on the other hand, the Board held a discharge unlawful where the employee, one of several drivers who responded to radio instructions without having a permanent route, refused to cross a picket line at a plant where he was told to stop, thus forcing another driver to make the trip. The Board's explanation-that such discharges are lawful "only when the employer's business need to replace the employees is such as clearly to outweigh the employees' right to engage in pro. tected activity"27-does not distinguish two similar cases that have different results. It adverts to a conflict of interests but does not give clear guidance about the proper weight to be given to those interests.

Where the employer leaves the picketed work temporarily undone, it is similarly uncertain in any particular instance whether he may discharge the employee. In order to satisfy the Redwing exception, not only must the employer be able to secure a replacement "immediately or within a short period of time," 28 but he must also be able to prove that the discharge was necessary "to preserve the efficient operation" of his business. ${ }^{29}$ Precise standards do not exist for judging when an act is sufficiently important for maintaining efficiency to justify a discharge.

Thus, under Redwing, whether an employer arranges for another of his employees to do the picketed work and then discharges the picket line observer or whether he immediately discharges the employee in order to hire a replacement, ambiguous concepts are retroactively ap. plied by the Board to determine the lawfulness of the discharge. The parties $^{30}$ are not only denied the opportunity to assess accurately the

25. 166 N.L.R.B. No. 101 (1967).

26. 154 N.L.R.B. 1271 (1965).

27. Id. at 1274 .

28. In L.G. Everist, Co., 142 N.L.R.B. 193 (1964), the Board held unlawful the re. fusal of the employer to reinstate four employees discharged for refusing to cross a picket line since the four had requested reinstatement before they were replacel. The Court of Appeals, in reversing the Board, stressed that once an employec is discliarged an employer may enforce his rule against rehiring discharged employecs. $334 \mathrm{~F} .2 \mathrm{~d} \$ 12$ (8th Cir. 1964).

29. The urgency required of the employer by the customer to complete the unperformed, picketed work is relevant in determining the necessity of preserving the cfficlent operation of the business. Swaine \& Morris Construction Co., 168 N.L.R.J3. No, 147 (1967).

30. Ambiguity encompasses not only the employer's position but that of the cm. ployees as well. When confronted with a picket line which he would like to respect, an employee must first determine whether the particular line is lawful. This task, with 
legal consequences of their actions, ${ }^{31}$ but the entire affair is left open to extensive manipulation by the well-counseled employer. A discharge letter worded in terms of business necessity, correspondence indicating the urgency of the job, and apparent replacement of the discharged employee, all go a long way toward proving a discharge to be within the Redwing exception.

\section{The Proper Role of the NLRB}

\section{A. The Limits of Balancing}

In resolving the problem of an employer's rights when one or more of his employees refuse to cross a picket line at another employer's premises, the Board claims it is striking the "proper balance"32 between the rights of employees to engage in concerted activity under Section 7 and the rights of an employer to run his business efficiently.

The Supreme Court has explicitly recognized the balancing of interests as a proper function for the Board:

Clearly, where "the ultimate problem is the balance of the conflicting legitimate interests" it must be remembered that "The function of striking that balance to effectuate national labor policy is often a difficult and delicate responsibility, which the Congress committed primarily to the National Labor Relations Board, sub. ject to limited judicial review."33

On the other hand, the Supreme Court has not hesitated to admonish the Board for attempting to balance the economic porver of union and employer:

[T] he Act does not constitute the Board as an "arbiter of the sort

which the Board itself often has difficulty, an be impossible for the cmplojee. Yer, should he refuse to cross a line which is later declared unlawful, he has no protection, Drivers' Local 695 v. NLRB, 361 F.2d 547, 551 (D.C. Cir. 1960); should he cross a law:ful picket line, he is subject to a fine by his union for "conduct unbecoming a union member." NLRB v. Allis-Chalmers Mfg. Co., 388 U.S. 175 (I967).

31. Indicative of this uncertainty is that on at least two occasions, Swaine $\&$ Morris Construction Co., 168 N.L.R.B. No. 147 (1967), and Overnite Transportation Co., 154 N.L.R.B. 1271 (1965), the Board generally accepted the facts as found by the Trial Examiners, applied the Redwing doctrine to the facts, and jet arrived at conclusions opposite to those of the Trial Examiners.

A business which retains a labor attorney will normally seck advice before discharging an employee for an union-related activity; similarly, union counsel will often inform local leaders of the rights of their members to act in particular circumstances. It is for this Ieason that the ambiguity of the Redwing doctrine, which does not allow the parties to foresee the legal consequences of their actions, creates practical difficulties for both union and management.

32. Swaine \& Morris Construction Co., 168 N.L.R.B. No. I47, 67 L.R.R.M. 1039, 1010 (1967).

33. NLRB v. Insurance Agents' International Union, 361 U.S. 477, 499 (1960). 
of economic weapons the parties can use in seeking to gain acceptance of their bargaining demands." 34

These two positions of the Supreme Court present an apparent inconsistency: the role of balancing "the conflicting legitimate interests," approved by the Court, is effectuated by the Board's serving as an "arbiter of the sort of economic weapons the parties can use," the role explicitly disapproved by the Court. Prohibiting an employer from discharging an employee for certain action which the Board has labeled "protected" is a restriction on the employer's economic power, as exercised through his control over employment; yet making a determination that certain activities are protected is a recognized function of the Board. ${ }^{35}$

The explanation of the apparent inconsistency lies not in a recondite analysis of the supposed distinction between "weapons" and "interests" but in the realization that the function of Board intervention differs depending on the stage of the union-employer relationship in which it occurs. The central policy of the Labor-Management Relations Act - the promotion of collective bargaining as the favored means to industrial peace ${ }^{36}$-justifies certain Board interventions involving the adjustment of interests and weapons, but excludes interventions at other stages of the collective bargaining process, which nonetheless involve similar adjustments.

The encouragement of collective bargaining is provided, in part, by the guarantee to employees of "the right to self-organization, to form,

34. NLRB v. Brown, 380 U.S. 278, 283 (1965).

35. See note 7 supra.

36. Section 1 of the Labor-Management Relations Act, 29 U.S.C. \& 151, states:

It is hereby declared to be the policy of the United States to eliminate the causcs of certain substantial obstructions to the free flow of commerce and to mitigate and eliminate these obstructions when they have occurred by encouraging the practice and procedure of collective bargaining . . . .

The Supreme Court, in H. K. Porter Co. v. NLRB, 397 U.S. 99, 103 (1970), recently cx. plained:

The object of this Act was not to allow governmental regulation of the terms and conditions of employment, but rather to ensure that employers and their employees could work together to establish mutually satisfactory conditions. The basic theme of the Act was that through collective bargaining the passions, arguments and strtggles of prior years would be channeled into constructive, open discussions leading, it was hoped, to mutual agreement.

The provision in Section 7 protecting the right of employces "to refrain from any or all of such activities," added to the Act in 1947, does not cut back at all on thic Act's encouragement of collective bargaining. The freedom of employees to select a bargaining representative of their own choosing or to select no bargaining representi. tive at all, thereby permitting the employer to set the terms and conditions of employment unilaterally, is a necessary component of free collective bargaining. The government's protection of this freedom of choice, especially when compared with the situation that existed prior to the Act's passage in 1935, is itself indicative of the leglslation's encouragement of collective bargaining. 
join, or assist labor organizations." 37 It is during union organization that the Board, with court approval and assistance, has most often and most appropriately adjusted the conflicting interests of the employer with those of his employees. The organizational rights of employees have been balanced against the rights of employers to maintain discipline in their establishments, ${ }^{38}$ to prevent disruption of business, ${ }^{30}$ to preserve safety, ${ }^{40}$ and to control the use of their property. ${ }^{41}$ From decisions such as these, various rules governing union opportunities to solicit new members and employer response to such solicitation have emerged..$^{42}$ The Board, by balancing conflicting interests, is functioning to create "a climate within which employees can freely determine whether they wish to collectivize their employment relationship. . . ."43 Such balancing encourages union organization and, thus, is clearly consistent with the Act's policy of collective bargaining as the favored means of avoiding industrial conflict.

While the balancing done by the Board in setting up the rules which govern union organizing campaigns advances the purposes of the legislation, once a bargaining relationship has been established the need for the Board to accommodate conflicting interest no longer exists.

Having protected employee organization in countervailance to the employer's bargaining power, and having established a system of collective bargaining whereby the newly coequal adversaries might resolve their disputes, the Act also contemplated resort to economic weapons should more peaceful measures not avail. Sections $8(a)(1)$ and (3) do not give the Board a general authority to assess the relative economic power of the adversaries in the bargaining process and to deny weapons to one party or the other because of its assessment of the party's bargaining power."4

As Supreme Court decisions of the last decade have indicated, the NLRB should not use its powers to restrict either the employer's or the union's use of economic force. In both the American Shipbuilding $^{45}$ and $B$ row $n^{46}$ cases the Court rejected the balancing by the Board

37. Section 7 of the Act, p. 1369 supra.

38. Republic Aviation Corp. v. NLRB, 324 U.S. 793 (1945).

39. Marshall Field \& Co., 98 N.L.R.B. 88 (1952).

40. Great Atlantic \& Pacific Tea Co., 123 N.L.R.B. 747 (1959), enforced, 277 F.2d 759 (5th Gir. 1960).

41. NLRB v. Babcock \& Wilcox Co., 351 U.S. 105 (1956).

42. See generally Bok, The Regulation of Campaign Tactics in Representation Elec-

tions Under the National Labor Relations Act, 78 HARv. L. REv. 38 (1961).

43. H. WEIIINGTON, LABOR AND tHE LEGAL Process 45 (1968).

44. American Shipbuilding Co. v. NLRB, 380 U.S. 300, 317 (1965).

45. 380 U.S. 300 (1965).

46. NLRB v. Brown, 380 U.S. 278 (1965). 
and expanded the right of employers to lock out employees during negotiations. In the Insurance Agents case, ${ }^{47}$ the Supreme Court overruled the Board's holding that certain employee on-the-job activity designed to exert economic pressure on the employer during the negotiating period was unlawful. ${ }^{48}$ Although the activity was not pro. tected, ${ }^{49}$ and therefore subject to employer response, neither was it unlawful; both sides were free to flex their economic muscle.

Congress has mandated some Board intervention in the negotiation process by its imposition on both labor ${ }^{50}$ and management ${ }^{51}$ of the duty to bargain in good faith. While the vagueness contained in the statutory definition of good faith bargaining ${ }^{52}$ requires the Board to determine state of mind by examining the conduct of the parties, the Supreme Court has insisted that the good faith requirement does no more than authorize the Board to assure that the bargaining envisioned in the Act between the employer and the designated collective bargaining agent of his employees does in fact occur. ${ }^{53}$

It is implicit in the entire structure of the Act that the Board acts to oversee and referee the process of collective bargaining, leaving the results of the contest to the bargaining strengths of the parties. ${ }^{54}$

The duty to bargain in good faith, while requiring limited Bonrd intervention in the negotiation process, is meant to guarantee meaning to the selection by employees of a bargaining representative and is thus consistent with the position that balancing by the Board is appropriate only to protect the organizational interests of employees. ${ }^{65}$

47. NLRB v. Insurance Agents' International Union, 361 U.S. 477 (1960).

48. The Board had declared the on-the-job activity a violation of the Scction $8(b)(8)$ duty to bargain in good faith. 119 N.L.R.B. 768 (1957).

49. Local 232 UAWW v. Wisconsin Employment Relations Board, 336 U.S. 215 (1919).

50. Section $8(\mathrm{~b})(3)$ of the Labor Management Relations Act, 29 U.S.C. \& $158(b)(b)$ (1964).

51. Section 8(a)(5) of the Labor Management Relations Act, 29 U.S.C. $\& 158(a)(5)(1961)$.

52. Section 8(d) of the Act, 29 U.S.C. \& 158(d):

For the purposes of this section, to bargain collectively is the performance of the mutual obligation of the employer and the representative of the employecs to mect at reasonable times and confer in good faith with respect to wages, hours, and other terms and conditions of employment. ....

53. H. K. Porter Co. v. NLRB, 397 U.S. 99, 103 (1970).

54. 397 U.S. at 107-08.

55. Certain lower federal courts have assigned an independent rather than a suppor. tive role to the good faith requirement and have, for example, determined that particular bargaining techniques are less likely to lead to agreement than others and hence are prohibited as not in good faith. Such balancing as is then required serves the undesirnble function of attempting to equalize the power of the parties. See H.K. Porter Co. V. NLIRI, 414 F.2d 1123 (D.C. Cir. I969), reversed, 397 U.S. 99 (1970); NLRB v. Recd \& Prince Manufacturing Co., 205 F.2d 131 (1st Cir.), cert. denied, 346 U.S. 887 (1953). See Generally H. WeI,LINGton, LABOR AND THE LeGal Process 55-56 (1968). 
While some governmental structuring of labor-management interests is in fact present during negotiations, ${ }^{50}$ any adjustment of conflicting interests by the NLRB and the courts once a collective bargaining agreement has been signed directly contradicts the policy of free collective bargaining as the desired means of industrial dispute settlement. ${ }^{57}$ Collective bargaining is itself the method by which the parties themselves adjust their rights and conflicting interests to serve their own needs.

The Wagner Act became law on the floodtide of the belief that the conflicting interests of management and worker can be adjusted only by private negotiation, backed, if necessary, by economic weapons, without the intervention of law. 58

Thus, collective bargaining agreements commonly include no-strike clauses, bargained and presumably paid for by the employer, which deprive the employees of statutory rights. Similarly, restrictions on the employer's free operation of his business are a major part of every collective bargaining agreement, these restrictions being bargained and paid for by the union. With the exception of those rights relating to union organization, ${ }^{59}$ all Section 7 rights are subject to negotiation and

56. Besides the good faith bargaining requirement, Congress itself has balanced some economic weapons, for example, by prohibiting in Section $8(b)(4)$ of the Act various forms of secondary boycotts. 29 U.S.C. $\$ 158(\mathrm{~b})(4)$. This balancing by Congress perhaps provides additional support for the proposition that the Boand should refrain from so doing.

Yet the Board has continued to balance the conflicting weapons of emplojer and cmployees during negotiations, the classic example being the strike, an aberration which can only be explained by the special status granted strikes in the Act itself (in Section 13 as well as Section 7) and in American labor lore.

57. The one exception to this rule is the Board's protection of organizing interests, which are not subject to negotiation by the parties. See note 59 infra. This area of per. missible Board intervention is consistent with the general proposition that Board balancing is appropriate in the organizational process. See p. 1377 supra. See also note 72 infra, concerning Section 8(a)(3) violations, and p. 1378 supra, which includes a discussion of the good faith bargaining requirement.

Court approval of Board orders directing emplojers, despite explicit wiver by the unions in the contracts themselves, to bargain on matters not specifially covered in their operative collective agreements in effect nullify express lawful provisions negointed by the parties. See, e.g., NLRB v. C \& C Plywood Corp., 385 U.S. 421 (1967). The Act does not justify such judicial and administrative interference. See also NLRB v. Acme Industrial Co., 385 U.S. 432 (1967), and Unit Drop Forge Division, Eaton, Yale \& Towne, Inc. v. NLRB, 412 F.2d 108 (7th Cir. 1969).

58. Cox, The Right to Engage in Concerted Activities, 26 IND. L.J. 314, 322 (1951).

59. The freedom of employees to choose a particular union as their bargaining representative, to select a rival union to replace the certified representative, or to elect not to be represented or no longer to be represented by any union is an inherent part of the Act's policy of free collective bargaining. Since rival unions and anti-union emplojecs are not represented at the bargaining table, a certified union's bargaining away of opposition rights defeats this part of the Act's policy, and therefore should be unlawful. But the Courts of Appeals are not even in agreement on this point. Compare NLRB v. Gale Products Division of Outboard Mfarine Corp., 337 F.2d 390 (7th Cir. 1964), where the court held valid the impartial enforcement of a collective bargaining agreement provision 
adjustment by the parties themselves. ${ }^{\circ 0}$ Board intervention, in the form of balancing interests, functions, during the life of a contract, not to promote collective bargaining but to replace it. In effect, it inserts a substantive term or condition into the employment relationship. In* tervention having this function cannot be justified by the goals of the Act.

\section{B. Picket Line Observance}

In light of the discussion of the Board's role in balancing interests in the collective bargaining process, an examination of the stages of the union-employer relationship in which the picket line observance prob. lem occurs suggests that at no time would Board intervention function to promote collective bargaining.

The picket line observance problem arises most often where a collective bargaining agreement is in existence. It is the union member, usually working under a negotiated contract, who is most likely to observe the picket line at the premises of another employer. ${ }^{01}$ In such a situation, where the picket line-observing employee's terms and conditions of employment have been negotiated by his certified repre. sentative and his employer, intervention by the National Labor Relations Board is most objectionable.

The Board's adjustment of the conflicting interests, presently expressed in the Redwing doctrine, prevails only when the parties themselves have failed to negotiate their own accommodation. Yet, the Act requires labor and management to negotiate all "conditions of employment." ${ }^{2}$ In applying the Redwing resolution to a particular case, the

prohibiting the distribution of union literature or solicitation of union membership on company premises, with NLRB v. Mid-States Metal Products, Inc., 403 F.2d 702 (5th Cir. 1968), in which the court enforced a Board decision finding the employer's enforcement of a collective bargaining agreement provision which prohibited soliciting or collecting con. tributions and distributing literature on company premises an unfair labor practice.

60 . Even where the Board or the Court has balanced economic weapons, the partics may establish their own adjustment of the interests, a resolution which prevails over onc administratively or judicially created. In Mastro Plastics Corp. v. NLRB, 350 U.S. 270 (1956), for example, the Supreme Court, after holding that a strike in protest of an employer's unfair labor practice does not violate a general no-strike clause in the collective bargaining agreement, indicated, "We assume that the employees, by explicit contractunl provision, could have waived their right to strike against such unfair labor practices. . . ." 350 U.S. at 279.

61. This is especially true if the picketing is being conducted by another local of hils own union or by a union which has received the formal support of the employec's union. The Teamsters Union, for instance, often recognizes certain picket lines and refuses to respect others, its decisions being motivated primarily by inter-union politics.

62. As part of their duty to bargain in good faith, the parties are required to negotinte any issue raised by either side if it is a "term or condition of employment." 29 U.S.C. $\S 158(\mathrm{~d})$. See Fibreboard Paper Products Corp. v. NLRB, 379 U.S. 203 (1961); NLIRB v. Wooster Division of Borg-Wamer Corp., 356 U.S. 342 (1958). 
Board, by its adjustment of the conflicting interests, is writing a clause of the collective bargaining agreement for the parties. Such interference by the Board is in direct opposition to the policy of free collective bargaining. ${ }^{63}$ The proper resolution of the problem, where the agreement does not specifically cover picket line observance, is the procedure the parties themselves have provided in their contract for handling disputed discharges. ${ }^{64}$

The problem of an employer's rights when an employee refuses to cross a picket line can also arise during contract negotiations, but the policy of Board abstention should still prevail. During negotiations, when employees are particularly sensitive to union allegiance, observance of other workers' picket lines may be intended both to symbolize worker unity and to pressure their own employer into yielding to their demands. If the old contract has not yet expired, the terms of that agreement, of course, govern the problem. Once those provisions expire, the observance of picket lines at the premises of other employers, like other forms of economic pressure applied during negotiations, can be freely exercised and freely responded to. ${ }^{05}$ With the parties sitting at the bargaining table at the time anyway, any discharges related to the picket line observance problem, as well as the problem itself, can be immediately negotiated, a collectively bargained solution being the most desirable resolution.

When the employee of an unorganized employer refuses to cross a picket line at another employer's premises, letting the Board determine the legal rights of the parties by balancing their conflicting interests would again not encourage collective bargaining, but might, in fact, discourage it. Employees who have chosen a bargaining representative may very well have no protection in their collective bargaining agreement against employer discipline of employees who observe picket lines; those employees who have elected not to organize would, on the other hand, retain the benefits of the Board's intervention. The unorganized employer, rather than unilaterally setting terms and conditions of employment, would have his decisions reviewed by the NLRB.

63. In H. K. Porter Co. v. NLRB, 397 U.S. 99, 102 (1970), the Supreme Court reiterated:

[W]hile the Board does have power under the Labor Mranagement Relations Act, 61 STAT. 136, as amended, to require emplojers and emplojees to negotiate, it is without power to compel a company or a union to agree to any substantive contractual provision of a collective bargaining agreement.

64. The discharge of an emplojee for his refusal to cross a picket line at the premises of another employer, under most contracts, should proceed as a union challenge to a dis. charge it claims to be without cause.

65. See pp. 1377-78 supra. 
Thus, in those situations in which the Board's balance gives employees a greater measure of support than a particular union could produce at the bargaining table, the employees are better off without a union. Board intervention that has such an effect has no place in the Act's scheme.

When, as part of their own organizing efforts, the employees of a non-union employer refuse to cross a picket line at the premises of another employer, the Board's role should, in theory, be different. Since one of the interests involved is the employees' right to organize, this is the one instance where the NLRB should balance all the conflicting interests present. ${ }^{6 B}$ However, an examination of the alternatives open to the Board indicates that even in this situation the Board should not restrict the employer's right to discharge.

A Board balance that results in a compromise of conflicting interests is effective in other organizing situations where, for example, the scope of allowable union solicitation can be defined by relatively precise spatial and temporal limitations. ${ }^{\circ 7}$ In the picket line observance context, however, a compromise balance would lead to ambiguity, as the Redwing doctrine illustrates. ${ }^{88}$ The critical characteristic of any rule applicable during an organizational campaign and involving pos-

66. See p. 1377 supra.

The one other situation involving the right of employees to organize is the observance of an organizational picket line. Such a situation, however, does not affect the rights of picket line observers. Since organized employees can bargain away the right to cross any picket line (see note 75 infra), including an organizational picket line, the arguments against Board intervention where collective bargaining agreements do not contain specific provisions governing picket line observance (see pp. 1380-81 stupra) and where there is no union (see pp. 1381-82 sttpra) prevail. In the unlikely case where the pickets and the picket line observers are both acting to advance their own organizational rights, the balance (see pp. 1382-84 infra) would shift only slightly while the ambiguity if any protection were granted would increase significantly.

67. See, for example, Republic Aviation Corp. v. NLRB, 324 U.S. 793 (1945), where the Court approved the Board's rule that an employer may prohibit union solicitation by employees on company property during working hours, but not before or after working hours, and Stoddard-Quirk Manufacturing Co., 138 N.L.R.B. 615, 621 (1962), where tho Board announced, in reference to the distribution of union literature, that "we belicve organizational rights in that regard require only that employees have access to nonworking areas of the plant premises."

68 . It is difficult to imagine an unambiguous standard for resolving the picket line observance problem that would effectively compromise the interests of the cmployer in the efficient operation of his business and that of his employees in advancing labor unity and assisting the organizing of their co-workers. The Board, in its Rockatuay Netus decl. sion, 95 N.L.R.B. 336 (1951), declared the observance of a picket line protected, but granted the employer the right to require the employec to vacate his job and assume the position of a full striker. This solution, which was rejected by both the Second Circult Court of Appeals, 197 F.2d 111, 114-15 (1952), and the Supreme Court, 345 U.S. 71, 75 (1958), is the practical equivalent of a rule prohibiting the observance of picket lines at other em. ployers' premises, while permitting an employee to strike and thereby assume the liabilitics contained in the balance involving the right to strike. Such a solution can hardly be considered a compromise balance for the problem of picket line observance, since by forcing the picket line observer to become a full striker, it simply eliminates picket line observance as an act distinct from a strike. 
sible discharges ${ }^{69}$ is clarity and consistency in result; vague standards which do not enable the parties to pre-determine the lawfulness of discharges for particular actions increase the likelihood of the parties acting to precipitate discharges, and the discharge of a union adherent is the event most detrimental to the organizational process. ${ }^{\circ 0}$ The need for a clear rule to guide actions requires that a choice be made between one of the two easily applied alternatives to a compromise balanceeither total protection or no protection at all.

As an organizing tool, the refusal to cross a picket line at another employer's premises is of limited value to the union. While the tactic might enhance the feeling of union solidarity and demonstrate the increased power workers acquire by mutual cooperation, it has relatively little effect on the ability of employees to cast knowledgeable votes in the representation election. The real strength in the observance of picket lines at the premises of other employers is the pressure it places on the employer of the picket line observers to coerce some of his other employees into selecting the union. Such coercion, which works to defeat the statutory policy of employee free choice, ${ }^{71}$ would be the consequence of granting complete protection.

The no-protection alternative, however, would retain the certainty necessary in dealing with discharges while still protecting employee free choice. Moreover, the cost to the union of the no-protection alternative would not be great; the relatively indirect tactic of picket line observance would not be protected but the union would be free to risk its use if it wished. Adoption of such a balance of the interests-granting no protection against discipline to employees who during the course of an organizing campaign at their own plant refuse to cross a picket line at the premises of another employer-iwould mean that here as

69. Where the possibility of discharge is not involved, the need for clear-cut rules is less compelling. For example in NLRB v. Babcock \& W Wilcox Co., 351 U.S. 105 (1950), the Court ruled that "an employer may validly post his property against non-emplojee distribution of union literature if reasonable efforts by the union through other avilable channels of communication will enable it to reach the employees with its message. . .." (emphasis added). 351 U.S. at 112.

70. See Bok, The Regulation of Campaign Tactics in Represenlation Elections Under the National Labor Relations Act, 78 HARv. L. REv. 38, 125 (1964).

71. Elsewhere the statute specifically treats an analogous problem. Section $8(\mathrm{~b})(7)$ of the Act, 29 U.S.C. $\S 158(\mathrm{~b})(7)$, was intended to curb organizational and recognitional picketing in order to protect against similar coercion on the picketed emplojer to bargain with a particular union not necessarily desired by a majority of his cmplojecs. "Section 8 (b)(7) was a logical response to values embodied in the Wagner Act and clarified by the Taft-Hartley Act. Free choice by individual employees with respect to unionization and majority rule by the uncoerced members of an appropriate bargaining unit were central objectives of the Wagner Act." Meltzer, Organizational Picheting and the NLRB: Five on a Seesaw, 30 U. GH. L. REv. 78, 79 (1962). 
elsewhere the parties would be left free, without Board interference, to resolve the problem themselves. ${ }^{72}$

\section{Conclusion}

Board abstention when an employee refuses to cross a picket line at the premises of an employer other than his own would have several desirable consequences. Most importantly, employers and unions would be encouraged to adjust their conflicting interests through negotiation, rather than relying on the adjustment worked out by the NLRB. ${ }^{73}$ A union particularly desirous of the right to respect other employer's picket lines would be willing to sacrifice other benefits in return for a clause protecting its members from discipline for refusing to cross such picket lines. ${ }^{74}$ Those employers particularly concerned with work to be done by their employees outside their own

72. While this Note argues for the elimination of Section 8(a)(1) protection for refusals by employees to cross picket lines at premises of employers other than their own, the discharge of an employee for such a refusal could conceivably be an unfair labor practice under Section 8(a)(3) of the Act, note 3 supra. The discharge of an employec for cngaging in unprotected activity is not unlawful, even when only some of those employecs engaging in the activity are discharged. California Cotton Cooperative Association, 110 N.L.R.B. 1494 (1954). On the other hand, an employer who uses the observance of a picket line as an excuse to discharge an employee for having engaged in prior protected activity, c.g, a discharge resulting from an employer's purposeful transfer of a union organizer to a job the employer knows will involve crossing a picket line, commits an unfair labor practice under Section 8(a)(3). For example, in Truck Drivers Local $728 \mathrm{v}$. NLRB, 364 F.2d 682 (D.C. Cir. 1966), the court avoided a decision on whether the refusal to cross $a$ picket line was "protected" by affirming the Board's finding of an $8(a)(3)$ vialation based on other employer actions demonstrating his anti-union animus; on that basis the court affirmed the reinstatement order issued by the Board.

The concept of "protected" activity, as developed in this Note, is necessarily limited to union organizing efforts and internal union matters not directly affecting the cmploycr. As such, Board intervention to enforce Section $8(a)(3)$ violations, although possibly occuring during negotiations or while a contract is in effect, does not contradict the proposition that balancing by the Board is appropriate only to protect the organizational interests of employees. See note 57 supra.

73. In its Rockaway News decision, the Supreme Court, in reference to the Section 8(b)(4) proviso on the right of employees to refuse to cross picket lines, stated

This [the proviso] clearly enables contracting parties to embody in their contract a provision against requiring an employee to cross a picket line if they so agrce. And nothing in the Act prevents their agreeing upon contrary provisions if they consider them appropriate to the particular kind of business involved. An employeces breach of such an agreement may be made grounds for his discharge without vlolating $\$ 7$ of the Act.

345 U.S. at 80.

Although Section 8(e), added to the Act in 1959, prohibits hot cargo clauses, the Courts of Appeals have continued to hold valid provisions in collective bargaining ayrectments which prohibit discipline of employees who refuse to cross lawful primary picket littes. See, e.g., NLRB v. Bay Counties District Council of Carpenters, 382 F.2d 509 (9th Cir. 1967); Drivers Local 695 v. NLRB, 361 F.2d 547 (D.C. Cir. 1966); Truck Drivers Local 413 v. NLRB, 334 F.2d 539 (D.C. Cir.), cert. denied, 379 U.S. 916 (1964).

74. Thirteen per cent of all collective bargaining agreements specifically prohibit discipline of individuals who refuse to cross lawful picket lines at the premises of other employers. 2 BNA, Collective BaRgaining: Necotistions aNd Contructs 77:5 (1964). 
premises would be sure in their negotiations to favor a no-strike clause, specifying the obligation of employees to cross all picket lines ${ }^{75}$ even where the consideration for such a clause would be costly. The encouragement of negotiations between the parties them. selves would be in complete accord with the purposes of the national labor legislation:

The object of this Act was not to allow governmental regulation of the terms and conditions of employment, but rather to ensure that employers and their employees could work together to establish mutually satisfactory conditions..$^{70}$

For those employers and unions who would not feel the necessity of bargaining for such contract provisions, freedom from governmental interference would allow them to choose appropriate responses on those few occasions when the problem might arise. Employee action followed by employer reaction would initiate the grievance dispute settlement procedure agreed to by the parties; arbitration would replace NLRB determination.

The advantages of this substitution would be substantial. The adjustment by the Board is formulated so as to apply to all employers covered by the Act. Considerations present in a particular case may have been absent in the Board's general calculations, thereby making the balance drawn by the Board inappropriate. ${ }^{77}$ On the other hand, in order to compensate for the particular differences in each case, the rule is necessarily general, resulting in the ambiguities inherent in the Redwing doctrine and producing uncertainty of result and possible manipulation of outcome.

In contrast, an arbitrator resolving a conflict can look to the provisions of the particular contract, the general intent of the parties, and any unique circumstances present in the case.

The labor arbitrator is usually chosen because of the parties' confidence in his knowledge of the common law of the shop and their trust in his personal judgment to bring to bear considerations

75. Over $90 \%$ of all collective bargaining agreements contain some type of no-strike clause. 2 BNA, Collectrve Barganing: Necotiations and Contsucts 77:1 (1964). Afany of these provisions would be interpreted to allow the immediate discharge of an $\mathrm{cm}$ ployee for refusing to cross a peaceful picket line. The Supreme Court in its Rochaviay News decision specifically acknowledged and accepted the arbitrator's decision that the no-strike clause in the parties' contract enabled the emplojer to discharge the picket line-observing employee. See p. 1371 supra.

76. H.K. Porter Company v. NLRB, 397 U.S. 99, 103 (1970).

77. "[T] he law cannot possibly anticipate the content of an infinite number of atypical transactions into which members of the community may need to enter." Kessler, Contracts of Adhesion-Some Thoughts about Freedom of Contract, 43 Colvar. L. REv. 639 (1943). 
which are not expressed in the contract as criteria for judgment. The parties expect that his judgment of a particular grievance will reflect not only what the contract says but, insofar as the collective bargaining agreement permits, such factors as the effect upon productivity of a particular result, its consequence to the morale of the shop, his judgment whether tensions will be heightened or diminished. For the parties' objective in using the arbitration process is ... to make the agreement serve their specialized needs. ${ }^{78}$

On several occasions in the past arbitrators have dealt with other picket line observance problems, sometimes interpreting contracts specifically covering the situation, ${ }^{70}$ while at other times relying on more general clauses ${ }^{80}$ or setting up their own guidelines. ${ }^{81}$ There is no reason to believe Board abstention and increased reliance on arbitration would create any unusual problems, ${ }^{82}$ especially since a party dissatisfied with a particular result could negotiate a change in the contract when it expires. The Act states explicitly that

Final adjustment by a method agreed upon by the parties is hereby declared to be the desirable method for settlement of grievance disputes arising over the application or interpretation of an existing collective bargaining agreement. ${ }^{83}$

Finally, the employees will benefit from Board abstention and the consequent encouragement of negotiation of picket line observance.

78. United Steelworkers of America v. Warrior \& Gulf Navigation Co., 363 U.S. 574, $582(1960)$.

79. See, e.g., Alfred M. Lewis, Inc., and Teamsters Locals 542 and 688, 50 L.A. 558 (R. Meiners, 1968); McKesson \& Robbins, Inc., Miami Drug Division and Teamsters local 390, 37 L.A. 847 (J.W. McConnell, 1961); Moon Freight Lines, Inc. and Teamsters Local 135, 36 L.A. 852 (J.J. Willingham, 1961); F.K. Trucking Co. and Produce Purveyors Local 202, 34 L.A. 252 (B. Turkus, 1959); Pilot Freight Carriers, Inc. and Teamsters Local 891, 22 L.A. 761 (D. Maggs, 1954).

80. See, e.g., Allied Chain Link Fence Company and United Steelworkers of America, 67-1 CCH LAB. ARB AwARDS 3510 (J. Giles, 1967); Arkansas Louisiana Gas Company and Oil, Chemical and Atomic Workers Local 5-283, $42 \mathrm{~L} . \mathrm{A} .626$ (W. Quinlan, 1946).

81. See, e.g., Gulf Coast Motor Lines, Inc., 49 L.A. 261 (R.R. Williams, 1967); Waterfront Employers Association and Longshoremen Local 1-10, 4 L.R.R.M. 1117 (Wayne L. Morse, 1939).

82. While a contention by the union that an employee's discharge for refusing to cross a picket line at another employer's premises was really motivated by his prior protected union activity, see note 72 supra, would be passed on by the arbitrator, the union could still file a Section 8(a)(3) charge with the Board. In International Harvester Co., 198 N.L.R.B. 923 (1962), aff'd sub nom. Ramsey v. NLRB, 327 F.2d 784 (7th Cir.), cerl. denied, 377 U.S. 1003 (1964), the Board stated, at 925-26:

[T] here is no question that the Board is not precluded from adjudicating unfair labor practice charges even though they might have been the subject of an arbitrator proceeding award. . . However, it is equally well established that the Board has considerable discretion to respect an arbitration award and decline to exercise its authority over alleged unfair labor practices if to do so will serve the fundamental aims of the Act.

83. Section 203(d) of the Act, 29 U.S.C. $\S 173($ d) (1964). 
The inclusion of a clause in the collective bargaining agreement covering an employee's rights on approaching a picket line frees the individual employee from the conflicting pressures of union loyalty and retention of employment. His course of conduct is dictated by the terms agreed to by his union and his employer.

$[P]$ arties generally are wiser about their own affairs than others, including government acting through its legal institutions, can hope to be. ${ }^{84}$

The National Labor Relations Act is apparently based on this premise; the National Labor Relations Board's actions in regard to an employee's observance of a picket line at the premises of an employer other than his own seem intent on denying it.

84. H. Weilington, Labor and the legal Prockss 29 (1968). 